\title{
Wyrok Sądu Metropolitalnego w Katowicach (c. Sobański) z 7.7.2003 : niezdolność do podjęcia istotnych obowiązków małżeńskich
}

Ius Matrimoniale 9 (15), 223-230

2004

Artykuł został zdigitalizowany i opracowany do udostępnienia w internecie przez Muzeum Historii Polski w ramach prac podejmowanych na rzecz zapewnienia otwartego, powszechnego i trwałego dostępu do polskiego dorobku naukowego i kulturalnego. Artykuł jest umieszczony w kolekcji cyfrowej bazhum.muzhp.pl, gromadzącej zawartość polskich czasopism humanistycznych i społecznych.

Tekst jest udostępniony do wykorzystania w ramach dozwolonego użytku. 
Ius Matrimoniale

9 (15) 2004

\section{Wyrok Sądu Metropolitalnego w Katowicach (c. Sobański) z 4.7.2003 (niezdolność do podjęcia istotnych obowiązków małżeńskich)}

\section{Przebieg sprawy:}

AK oraz MM zawarli małzeństwo 31.7.1999. Pismem z 6.2.2002 AK zwrócił się do Arcybiskupa Metropolity Katowickiego „o poparcie starań o dyspensę papieską od małżeństwa niedopełnionego". Sprawę przyjęto 25.2.2002. Dnia 11.3.2002 przesłuchano strony. Wobec wyraźnego zeznania żony o dokonaniu małżeństwa, a także wobec wyników badania ginekologicznego przeprowadzonego przez biegłego sądowego, poinformowano 7.5.2002 AK, że sprawa o dyspensę od małżeństwa niedopełnionego nie może być dalej prowadzona. Równocześnie powiadomiono go o wniesieniu przez żonę skargi o orzeczenie nieważności małżeństwa. AK w piśmie z 10.6.2002 stwierdził, że „poczuł się skrzywdzony i oburzony treścią” pisma, zarzucił Sądowi „wyraźną stronniczość”, „brak logiki”, niesprawiedliwość, a wskutek „odrzucenia" jego zeznań czuje się obrażony, przekazał też Sądowi szereg pouczeń. Poinformowano go, iż ma prawo odwołania się do Kongregacji Kultu Bożego i Sakramentów. Do procesu o nieważność małżeństwa przyjęto sprawę 16.3.2002. Przedmiot sporu ustalono 31.5.2002 w formie pytania: „czy zachodzi nieważność małżeństwa stron z tytułu niezdolności do podjęcia istotnych obowiązków małżeńskich po stronie pozwanego oraz/lub powódki?".

\section{Motywy prawne:}

„Małżeństwo cieszy się przychylnością prawa, dlatego w razie wątpliwości należy uważać je za ważne, dopóki nie udowodni się czegoś przeciwnego" (k. 1060). Norma ta chroni instytucję malżeństwa, ale jest też wyrazem zaufania do nupturientów, zakłada bowiem ich zdolność do małżeństwa i prawidłowość ich woli małżeńskiej. Kto przeto 
twierdzi, że małżeństwo jest nieważne, przejmuje na siebie ciężar dowodu. Dotyczy to także twierdzenia o niedopełnieniu małżeństwa: „gdy po zawarciu małżeństwa małżonkowie wspólnie zamieszkali, domniemywa się dopełnienie, dopóki coś przeciwnego nie zostanie udowodnione" (k. 1061 §2). Małżonek twierdzący, że małżeństwo jest ważne wzgl. że zostało dopełnione, ma za sobą domniemanie prawne, małżonek twierdzący inaczej musi to domniemanie obalić.

Jeśli zachowano normy dotyczace kanonicznej formy zawarcia małżeństwa, przyczyną nieważności może być albo przeszkoda małżeńska albo defekt woli małżeńskiej. Sprawę można - i trzeba - przyjąć do procesu o nieważność wtedy, gdy w skardze podano fakty uzasadniające twierdzenie o nieważności oraz wskazano dowody na ich poparcie (k. 1504 n. 2). Do Sądu należy ustalenie zakresu sporu i sformułowanie jego prawnej podstawy (k. $1513 \S 1$ ).

Kan. 1095 n. 3 brzmi: „Niezdolni do zawarcia matżenstwa sq ci, którzy z przyczyn natury psychicznej nie sa zdolni podjać istotnych obowiazków malżeńskich". Dyspozycja ta bazuje na założeniu, że nikt nie może prawnie zobowiązać się do tego, czego nie potrafi wykonać. Jest to elementarna zasada prawa natury, akcentowana już w starożytnych i średniowiecznych źródłach prawa (Reg. 6 in VI). K. 1095 n. 3 konstatuje niezdolność z przyczyn natury psychicznej. Przyczyn tych nie należy utożsamiać $z$ chorobą psychiczną, aczkolwiek choroby takie mogą się wśród nich mieścić. Niezdolność do podjęcia istotnych obowiązków nie przekreśla zdolności do rozeznania ani w ogóle „zdolności życiowych" danej osoby.

Aplikacja k. 1095 n. 3 wymaga przeto ustalenia, co należy rozumieć przez "istotne obowiqzki matżeńskie” oraz jakie przyczyny uniezdalniają do ich podjęcia.

Analiza tego, co składa się na istotne obowiązki malżeńskie, musi wyjść od ujęcia istoty małzeństwa. Wspólnota małżeńska to wedle nauki Soboru Watykańskiego II „glęboka wspólnota życia i mitości” (GS 48), obejmująca aspekty nie tylko fizyczne, lecz także duchowe. Zaistnienie takiej wspólnoty zakłada zdolność do wzajemnego oddania się i przyjęcia. Dzięki temu powstaje międzyosobowa jedność, w której wzajemna miłość małżonków odpowiednio się wyraża, rozwija i dojrzewa (por. GS 50). Chodzi - naucza Paweł VI - „o mitość petnq, to znaczy o tę szczególnq forme przyjaźni, poprzez która matżonkowie wielkodusznie dzielq między sobą wszystko, bez niesprawiedliwych wyjątków i egoistycznych rachub" (enc. Humanae vitae 9). Kłóci się z taką miło- 
ścią egoizm, szukanie siebie, tendencje do panowania i rządzenia, agresja wobec partnera. W świetle orzecznictwa kościelnego małżeństwo wymaga zdolności do oddania się drugiej osobie zarówno w sferze fizycznej jak i duchowej przy zachowaniu autonomii i godności osób; zdolności do przezwyciężania własnego egoizmu oraz do dostrzegania własnych niedostatków; krótko mówiąc: zdolności do wyjścia poza swój własny świat. Podkreślić przy tym trzeba wyłączność wspólnoty małżeńskiej, co oznacza oddanie się bez reszty i ofiarne współdziałanie dla wzajemnego dobra. Tego wszystkiego małżonkowie mają prawo wzajemnie oczekiwać, to wszystko składa się na małżenstwo i tym samym należy do jego kształtu prawnego..

Aby Sąd mógł orzec nieważność małżeństwa, musi osiągnąć moralną pewność o istnieniu określonych prawem - w tym przypadku $\mathrm{k}$. 1095 n. 3 - podstaw nieważności. Pewność tę może czerpać wyłącznie z akt sprawy, tj., z zawartych w aktach faktów i dowodów (k. 1608 § 2). Dopuszczenie i ocena dowodów należy do sędziego. Świadków przedstawiają strony, biegłych powołuje Sąd. Od biegłych w sprawach o nieważność małżeństwa wymaga się nie tylko wiedzy specjalistycznej, lecz także znajomości i akceptacji nauki Kościoła o małżeństwie. Ocena ich opinii należy do Sądu, który weryfikuje przesłanki opinii i rozważa wnioski w całokształcie materiału dowodowego (k. 1579 § 1).

Przedmiotem procesu - i konsekwentnie wyroku - jest tylko i wyłącznie kwestia nieważności małżeństwa.. Wyrok orzekający nieważność małżeństwa, także z powodu niezdolności osoby prawnie niezdolnej do zawarcia małżeństwa, nie ma charakteru dyskryminującego Sąd nie wypowiada się wtedy o winie, lecz o nieistnieniu węzła małżeńskiego. W szczególności orzeczenie nieważności małżeństwa na podstawie k. $1095 \mathrm{n} .3 \mathrm{w}$ żaden sposób nie dotyka problemu winy, opiera się bowiem na istotnym dla aplikacji tego kanonu założeniu „chciał, ale nie mógł". Dotyczy to zawsze konkretnego, rozpatrywanego i orzekanego przez Sąd małżeństwa, nie ma charakteru generalnego.

\section{Stan faktyczny:}

1. W pierwszym zeznaniu powódka podaje, że „główną przyczyną niepowodzenia” małżeństwa było „wspólne zamieszkanie z dziadkami pozwanego oraz bardzo silny związek i uzależnienie pozwanego od dziadków". Opowiada, że ani w trakcie znajomości przedślubnej ani po 
ślubie nie dostrzegła, by on jej pragnął w sensie fizycznym. Miała przed ślubem pewne obawy, jak to będzie $z$ pożyciem cielesnym po ślubie. Nie chciała zawierać małżeństwa, ale pozwany ją szantażował: „albo bierzmy ślub albo zrywamy ze sobą”. Pozwany „o byle co się obrażal”, ona dzwoniła i przepraszała - słyszała przy tym, że „obok telefonu stała ta jego babcia i mówiła mu, co on ma mówić". Po ślubie były problemy z pożyciem intymnym. Odczuwała ból przy próbach współżycia, dopiero gdy „zmienili pozycję” udało się dopełnić małżeństwa. Tych stosunków nie było dużo, a tak na pewno przypomina sobie jeden.

Przeprowadzonym w związku z wniesioną prośbą o dyspensę od małżeństwa niedopełnionego badaniem przez ginekologa biegłego sądowego stwierdzono normalny stan ginekologiczny kobiety, która odbywała już stosunki płciowe.

Zeznając w procesie powódka twierdzi, że na tle ,nadmiernego uzależnienia pozwanego od tych dziadków, a od babci w szczególności... rysuje się ta niezdolność pozwanego do kształtowania własnego życia, do samodzielnych decyzji, do budowania własnego małżeństwa i rodziny". Po ślubie pozwany - twierdzi powódka - żył jak za kawalera i nie potrafił zmienić swoich nawyków: ,gdy przychodził z pracy, to siadał u swej babci i jej potrafił przez godzinę opowiadać, co przeżył lub zaszło w pracy - ja siedziałam w naszym pokoju i czekałam na niego... Babci wszystko opowiadał, a do mnie nie miał słowa". Z kolei to babcia "traktowała pozwanego jak małe dziecko”. Gdy w końcu powódka nie wytrzymała i oświadczyła, że nie będzie „żyć ze starymi dziadami”, pozwany ją spakował i odwiózł do rodziców, a babcia pozwanego zadzwoniła do matki powódki i powiedziała, że ma jej już dość.

2. Pozwany zeznaje podczas pierwszego przesłuchania: „Nasze małżeństwo trwało 2 lata i 3 miesiące - wtedy powódka stwierdziła, że ona już takiego życia nie wytrzymuje, że takie małżeństwo nie ma sensu i wyprowadziła się w październiku 2001 roku do swoich rodziców. Ją w naszym małzeństwie męczyło wszystko - mieszkaliśmy u moich dziadków, starałem się być dobry dla powódki, byłem gotowy nieba jej uchylić, ale ona ze wszystkiego była niezadowolona, wszystko ją denerwowało, wciąż miała skwaszoną minę i nie było w niej żadnej radości życia. Gdybym przez miesiąc żył z powódką przed ślubem, to na pewno by tego ślubu nie było - byłem jednak wychowany po katolicku i moje religijne zasady nie pozwalały mi na to, aby wspólnie przed ślubem zamieszkać lub podjąć współżycie cielesne. Wydaje mi się jednak, że gdybym choć miesiąc $z$ nią pomieszkał przed ślubem, to na tyle zdo- 
łałbym ją poznać, aby się wycofać $z$ tego ślubu. Powódka była pod wielkim wpływem swej mamy - pamiętam jeszcze z czasu narzeczeństwa, jak matka powódki mówiła jej, że jak jej coś będą mówić w naszym domu, to ma powiedzieć: „tak”, a robić i tak po swojemu. Kiedy powódka ode mnie odchodziła i kiedy tym bardziej wybuchly te wszystkie jej żale i pretensje, powiedziała mi wtedy, że wyszła za mnie za mąż tylko dlatego, aby jej mamie było lżej - tzn. aby wyjść $z$ domu i odciążý́ jej rodziców w tych kwestiach finansowych dotyczących utrzymywania jej. To by tłumaczyło fakt, że powódka była ze wszystkiego niezadowolona i praktycznie nie starała się nawiązać ze mną więzi małżeńskiej. Ona nawet ze mną współżyć cieleśnie nie chciała - nie chciała mieć także dzieci z naszego małzeństwa".

Pozwany twierdzi zdecydowanie, że małżeństwo nie zostało skonsumowane, gdyż pozwana nie dopuszczała do tego. Już przed ślubem ujawnił się upór pozwanej, ale on, zakochany, nie zwracał na to uwagi. Po ślubie był spragniony zbliżeń cielesnych, ale powódka nie chciała z nim współżć, wciąż powtarzała, że ,jeszcze nie teraz”. Miała wciąż o coś pretensje, ale nie wyjaśniała, dlaczego nie chce podjąć współżycia cielesnego. Uważa - zeznał wtedy - że powódka nie dojrzała do małzeństwa.

Tak samo zeznaje pozwany w trakcie procesu. Trudno mu pogodzić się z twierdzeniem, że powódka czuła się obco w jego domu, bo praktycznie to ona wszystkim narzucała swoją wolę, ,rano zostawiała kartki, co będzie robić, o której wróci, czy będzie jeść obiad...". Zwykle wszystko robiono tak, jak ona sobie tego życzyła. Pozwany absolutnie nie zgadza się z zarzutem swego całkowitego uzależnienia od dziadków. Dziadkowie nie ingerowali w to małżeństwo. Pozwany remontował mieszkanie, ale powódka nie chciała w nim zamieszkać. Okazywanie jej dobroci „działało na nią jak płachta na byka”. Pozwany zaprzecza wszystkim szczegółowym zdarzeniom przytoczonym przez powódkę, przytacza inne na potwierdzenie swej tezy o jej niezdolności do małżeństwa.

3. Zeznawało pięcioro świadków. Rodzice powódki i dziadkowie pozwanego powtarzają wersję swojej strony. W ich zeznaniach trzeba oddzielić podawane fakty oraz interpretacje i opinie, zaś spośród relacjonowanych faktów wyłuskać takie, które mają znaczenie dla sprawy i są prawdziwe.

Matka powódki podaje, że już przed ślubem pozwany „stawiał warunek” i powódka „musiała się podporządkowywać”. Wedle świadka 
babcia pozwanego obrzydzała mu żonę. Z kolei powódka „nie mogła już na tę babcię patrzeć".

Ojciec powódki mówi o częstych telefonach babci, „zawsze z jakimiś pretensjami”. Mówi też, że „ta babcia przy nas narzekała lub wyśmiewała się z córki".

Babcia pozwanego zeznając zarzuca powódce upór i niechęć do słuchania jej rad - dotyczących stosunku do pozwanego (,nie powinna na siłę zmieniać przyzwyczajeń wnuka"), budowania więzi małżeńskiej („ale nic do niej nie przemawiało"), chwytania się prac domowych (,ja powódce nieraz mówiłam, że lenistwo jest jednym $z$ siedmiu grzechów głównych”). Powódka reagowała zawziętością i uprzedzeniem „na całe dobro, które od nas otrzymała", mówi świadek. Według świadka powódka była „niedojrzała do małżeństwa, strasznie leniwa, mało samodzielna i nieodpowiedzialna za swe czyny", ponadto bardzo niewdzięczna, a przecież - jak mówiły koleżanki świadka - „nie ma lepszego męża nad naszego wnuka".

Takie same zarzuty stawia dziadek pozwanego. Zaprzecza, by jego żona wtrącała się do małżeństwa stron, ale powiada: „gdy żona starała się dać powódce jakieś pouczenie, to wtedy zaczynały się wrzaski”. Świadek dzieli się też swoją oceną, gdy powiada, że gdyby powódka kochała pozwanego, chodziłaby z nim na Mszę św. na godzinę $8^{\circ 0}$, ale ona często spała.

Koleżanka powódki, HS, uważa pozwanego za człowieka dziwnego, przyzwyczajonego do rozkazywania i stawiania warunków, mającego wciąż jakieś uwagi i pretensje. Już przed ślubem raziło świadka traktowanie powódki przez pozwanego: „ona nie mogła mieć swojego zdania", musiało być tak, jak on powiedział. Świadek bywała u stron, ale w tym domu „była jakaś dziwna atmosfera - babcia wtrącała się we wszystko, nie cierpiala sprzeciwu ani innego zdania". Do pozwanego nie docierało, że postępuje dziwnie, a nawet niestosownie.

4. Biegła sporządziła opinię opierając się na aktach sprawy i na przeprowadzonym przez siebie badaniu.

Konkluzja biegłej brzmi: „W oparciu o analizę materiału dowodowego oraz wyniki badań psychologicznych uważam, że pozwany w chwili zawierania związku małżeńskiego był zdolny do podjęcia i wypełnienia istotnych obowiązków małżeńskich. U powódki obserwuje się w chwili zawierania związku małżeńskiego oraz w czasie jego trwania niedojrzalość osobowościową, która powoduje u niej brak zdolności do podjęcia i wypelnienia istotnych obowiązków małżeńskich". 
Biegła wykorzystała w swej opinii także zeznania świadków, a te gdy chodzi o krewnych jednej i drugiej strony - rażą subiektywnością. I tak np. dziadkom pozwanego, zarzucającym, że gdyby pozwana kochała pozwanego, chodziłaby z nim na Mszę św. o godz. $8^{\circ}$, w ogóle nie przychodzi na myśl, że tę ocenę można by odwrócić: gdyby pozwany kochał powódkę, pozwoliłby jej spać dłużej i poszedłby z nią na późniejszą Mszę św. W świetle takich pretensji mało prawdopodobnie brzmi twierdzenie pozwanego, jakoby próbował powódce uchylić nieba.

Pozwany i jego dziadkowie zdecydowanie zaprzeczają jego uzależnieniu od babci i jej wtrącaniu się w życie stron, ale przecież sama babcia skarży się, że powódka nie słuchała jej dobrych rad, nie przyjmowała pouczeń o grzechach głównych, a pozwany załączył do akt list swej babci do matki powódki, w którym babcia wykłada własną interpretację małżeństwa stron, pisze, że „wszyscy uważają, że powinna Arka po tyłku całować" i wytyka matce powódki błędy wychowawcze, co więcej, babcia przyszła razem z pozwanym przeglądać akta. Szereg zarzutów pod adresem pozwanego znalazło potwierdzenie w trakcie procesu, m.in. obawy powódki, że pozwany wykorzysta akta przeciw niej w rozprawie rozwodowej. Rzeczywiście pozwany nie tylko nie pytając się o zgodę i nie mając jej posługiwal się kamerą przy publikacji akt, ale fragmenty opinii biegłej wykorzystał $w$ rozprawie rozwodowej, którą wszczął domagając się orzeczenia rozwodu „z wyłącznej winy pozwanej".

Pozwany twierdzi, że w zeznaniach świadków powódki „prawie w każdym zdaniu jest kłamstwo”. Dowodem na kłamstwa powódki i jej świadków ma być list jego babci, który „, nie zawiera klamstwa”. Argumentacja pozwanego sprowadza się zatem do stwierdzenia, że kłamstwem jest to, co on za kłamstwo uważa. Gdy czyjeś zeznania pozwanemu nie odpowiadają, stwierdza, że świadek ,w tej sprawie nie powinna mieć nic do powiedzenia i nie powinna być w ogóle brana pod uwagę jako świadek". Swiadkowie zeznający nie po myśli pozwanego, to ,katolicy" w cudzystowie.

Decyzje Sądu nie po myśli pozwanego zostają przezeń określone jako stronnicze, pozwany z dużą łatwością i pewnością siebie zarzuca Sądowi niesprawiedliwość, dopatruje się układów. Usiłuje wyeliminować nie tylko świadka zeznającego niekorzystnie dlań, ale także przewodniczącego Sądu (por. pismo pozwanego do ks. Arcybiskupa Metropolity. Pozwany zgłasza pretensje - a to że korespondencji nie wysłano li- 
stem poleconym, a to że notatka nieczytelna (widocznie jednak wystarczająco czytelna, skoro pozwany określa ją jako „kłamliwą”), a to że brak przy podpisie nazwiska wikariusza sądowego.

Wyraźnie i dobitnie zaznacza się tendencja pozwanego do pouczania - i nie ma powodów do przypuszczenia, by tendencja ta i pretensjonalność budziła się wyłącznie w odniesieniu do Sądu

Z powyższych faktów procesowych rysuje się sylwetka pozwanego nie harmonizująca $z$ ustaleniami biegłej dotyczącymi pozwanego. Pozwanemu brak wglądu we własne zachowania, nie wykazuje on chęci zrozumienia racji drugich, oktrojuje innym własne stanowisko, wykazuje skłonność do przypisywania innym złych intencji, nie brak objawów u niego agresji. Sąd nie wyklucza, że pozwany jest przekonany o prawdziwości tego, co mówi i pisze. Ale właśnie ten sposób percypowania i interpretacji rzeczywistości uniemożliwia pozwanemu zaakceptowanie drugiej osoby, jeśli ta nie spełnia stawianych przezeń warunków i nie odpowiada jego oczekiwaniom.

Tak więc Sąd nie podziela opinii biegłej w części odnoszącej się do pozwanego, uznaje natomiast za uzasadnione wnioski bieglej odnoszące się do powódki.

Wobec takiego stanu sprawy Sąd stwierdza, że udowodniono, iż zawierając małżeństwo zarówno pozwany jak i powódka nie byli zdolni podjąć istotnych obowiązków małżeńskich. Sąd odpowiada przeto twierdząco na obydwa pytania procesowe i orzeka, iż udowodniono nieważność małżeństwa $z$ obydwu rozpatrywanych tytułów. 